\title{
Antimicrobial activity of some honey samples against pathogenic bacteria
}

\author{
S. Mahendran, D. Kumarasamy* \\ Botany Wing (DDE) Annamalai University, Annamalai Nagar - 608002, Tamil Nadu, India \\ *E-mail address: Kumarasamy@rediffmail.com
}

\begin{abstract}
The aim of the present research work to investigate antimicrobial activity of some honey samples six winter honeys six summer honeys collected from different regions of Western Ghats. The microbes used in this study are Staphylococcus aureus, Streptococcus pyogenes, Escherichia coli, Pseudomonas aeruginosa, and Proteus mirabilis. Antibacterial activity of the honeys was assayed using the Disc diffusion method. Noticeable variations in the antibacterial activity of the different honey samples were observed. Among the microbes Staphylococcus aureus is the most sensitive against all honey samples shows the maximum inhibitor zone compare to summer honeys.
\end{abstract}

Keywords: Antibacterial activity; Disc diffusion; Honey

\section{INTRODUCTION}

Honey is one of the oldest traditional medicines considered as traditional remedy for microbial infections. It is also recognized as an efficacious topical antimicrobial agent in the treatment of burns and wounds (Brudzynski, 2006). This leads to the search for different types of honey with antibacterial activity (Mullai and Menon, 2007). The healing effect of honey could be due to various physical and chemical properties (Snow and Manley-Harris, 2004). The floral source of honey plays an important role on its biological properties (Molan, 2002).

Honey is being used in a few hospitals, especially in the clinical treatment of ulcers, bedsores, burns, injuries and surgical wounds. The antibacterial properties of honey may be particularly useful against bacteria which have developed resistance to many antibiotics, e.g. Staphylococcus aureus, which is a major cause of wound sepsis in hospitals (Armstrong and Otis, 1995). Honey is thus an ideal topical wound dressing agent in surgical infections, burns and wound infections (Betts and Molan, 2002).The use of honey as a medicine has continued into the present-day medicine. It has been shown that natural unheated honey has some broad-spectrum antibacterial activity when tested against pathogenic bacteria, oral bacteria as well as food spoilage bacteria (Bassom et al., 1994, Mundo et al., 2004 and Lusby and Coombes 2005).

The antibacterial potency of honey has been attributed to its strong osmotic effect, naturally low $\mathrm{P}^{\mathrm{H}}$ (Kwakman and Zaat, 2012), the ability to produced hydrogen peroxide which plays a key role in the antimicrobial activity of honey (Kacaniova et al., 2011 and Wahdam,1998)and phytochemical factors. Numerous reports and clinical studies have demonstrated the antimicrobial activity of honey against a broad range of microorganisms, 
including multi-antibiotic resistant strains. Others studies demonstrated the antibacterial activity of honey against: Escherichia coli, Campylobacter jejuni, Salmonella entercolitis, Shigella dysenteriae (Adebolu, 2005 and Voidaou et al., 2011), Mycobacterium (Asadi-Pooya et al.,2003), Methicillin-resistant Staphylococcus aureus and Vancomymin-resistant Enterococci (Cooper et al.,1999 \& 2002 and Al-waili et al.,2005),Common gastrointestinal pathogenic bacteria(Lin et al.,2011), and the development of streptococcus pyogenes biofilms (Maddocks et al., 2012). The antifungal activity of the honey, especially anti-Candida activity (Irish et al., 2006, Koc et al., 2008 and Ahmad et al., 2012) has also been reported.

The present study aimed to evaluate the antibacterial activity of some honey samples collected from Theni District. The honey samples are classified into Summer honey (collected in the month of April) and Winter honey (collected in the month of October) Also antibacterial activities of Antibiotics like Commonly used in the treatment of infections cared by here resistant pathogenic bacteria were evaluated.

\section{MATERIAL AND METHODS}

\subsection{Honey samples}

Twelve honey samples (Six honey samples S1, S2, S3, S4, S5 \& S6 were collected in the month of April and six honey samples-W1, W2, W3, W4, W5 \& W6 collected in the month of October). All samples were collected from Thani District Western Ghats, India. Samples were stored in dark place at a room temperature $(25-35 \mathrm{c})$

\subsection{Bacterial Strains}

Strains of Escherichia coli, Pseudomonas aeruginosa, Proteus mirabilis, Staphylococcus aureus and Streptococcus pyogenes, were obtained from Rajah Muthiah Medical College and Hospital, Annamalai University, Annamalai naga-608002, India.

\subsection{Disc diffusion method}

Bauer et al (1966) Filter paper discs of $6 \mathrm{~mm}$ diameter were prepared. The discs were impregnated with the different concentrations of each honey 0.5 McFarland standard was prepared by wing due method (Koneman et al., 1992) and $5 \mathrm{ml}$ was into a sterile test tube. An inoculums of each isolate was prepared from subculture of bacterial suspension 4-5 colonies of each isolates were emulsified in sterile normal saline and the turbidity adjusted to $1.5 \times 10^{8}$ ( $\mathrm{Fu} / \mathrm{ml}$ (corresponding to $0.5 \mathrm{McFarland}$ standers). A sterile cotton swab was dipped into the standardized bacterial suspension and used to evenly inoculate the Mueller Hinton agar plates. They were allowed to dry for 3 to 5 minutes. Thereafter, all discs were placed on the plates and $\mu$ pressed gently to ensure complete contact with agar. A distance of at least $15 \mathrm{~mm}$ was maintained from the edges of the plates to present overlapping of inhibition zones. Amphicillin disc $(5 \mu \mathrm{g})$ was used as positive control. Fifteen minutes after the placement of discs, the plates were incubated for $24 \mathrm{~h}$ at $37^{\circ} \mathrm{C}$. After incubation the plates were examined and three diameter of the inhibition zone was measured in triplicates for each isolate. 


\subsection{Statistical analysis}

Data analysis results were expressed as means \pm standard deviation and differences between means were analyzed statistically using an analysis of variance (ANOVA) according to Fisher's PLSD test. Differences were considered significant whenP $\leq 0.05$.

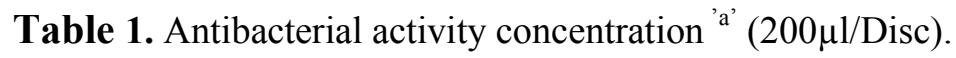

\begin{tabular}{|c|c|c|c|c|c|c|c|}
\hline Bacterial strains & S1 & S2 & S3 & S4 & S5 & S6 & $\begin{array}{c}\text { Am-B } \\
(\mathbf{5 \mu g} / \mathbf{d i s c})\end{array}$ \\
\hline $\begin{array}{c}\text { Staphylococcus } \\
\text { aureus }\end{array}$ & $12.5 \pm 0.80$ & $9.9 \pm 0.15$ & $9.8 \pm 0.50$ & $8.5 \pm 0.50$ & $8.1 \pm 0.15$ & $7.4 \pm 0.35$ & $7.1 \pm 0.28$ \\
\hline $\begin{array}{c}\text { Streptococcus } \\
\text { pyogenes }\end{array}$ & $10.1 \pm 0.32$ & $10.1 \pm 0.17$ & $9.3 \pm 0.43$ & $9.3 \pm 0.43$ & $8.3 \pm 0.35$ & $7.2 \pm 0.25$ & $8.0 \pm 0.50$ \\
\hline $\begin{array}{c}\text { E. coli } \\
\text { Pseudomonas } \\
\text { aeruginosa }\end{array}$ & $9.4 \pm 0.45$ & $9.2 \pm 0.34$ & $8.3 \pm 0.20$ & $8.2 \pm 0.25$ & $7.3 \pm 0.40$ & $7.1 \pm 0.28$ & $7.3 \pm 0.57$ \\
\hline $\begin{array}{c}\text { Proteus } \\
\text { mirabilis }\end{array}$ & $9.3 \pm 0.30$ & $9.1 \pm 0.15$ & $9.2 \pm 0.25$ & $8.2 \pm 0.25$ & $8.1 \pm 0.15$ & $8.0 \pm 0.51$ & $9.0 \pm 0.50$ \\
\hline
\end{tabular}

\begin{tabular}{|c|c|c|c|c|c|c|c|}
\hline Bacterial strains & $\mathbf{W 1}$ & $\mathbf{W 2}$ & $\mathbf{W 3}$ & $\mathbf{W 4}$ & $\mathbf{W 5}$ & $\mathbf{W 6}$ & $\begin{array}{c}\text { Am-B } \\
\mathbf{5} \boldsymbol{\mathbf { \mu g }} \mathbf{\text { disc }})\end{array}$ \\
\hline $\begin{array}{c}\text { Staphylococcus } \\
\text { aureus }\end{array}$ & $13.3 \pm 0.40$ & $11.5 \pm 0.25$ & $10.5 \pm 0.49$ & $9.4 \pm 0.40$ & $8.2 \pm 0.25$ & $8.2 \pm 0.25$ & $7.3 \pm 0.57$ \\
\hline $\begin{array}{c}\text { Streptococcus } \\
\text { pyogenes }\end{array}$ & $12.1 \pm 0.15$ & $11.4 \pm 0.40$ & $11.3 \pm 0.30$ & $10.0 \pm 0.57$ & $9.2 \pm 0.46$ & $9.2 \pm 0.52$ & $8.1 \pm 0.28$ \\
\hline E. coli & $11.0 \pm 0.25$ & $10.5 \pm 0.45$ & $10.2 \pm 0.52$ & $9.2 \pm 0.26$ & $9.3 \pm 0.43$ & $8.3 \pm 0.30$ & $7.5 \pm 0.50$ \\
\hline $\begin{array}{c}\text { Pseudomonas } \\
\text { aeruginosa }\end{array}$ & $10.9 \pm 0.11$ & $11.1 \pm 0.32$ & $9.9 \pm 0.10$ & $9.5 \pm 0.55$ & $8.3 \pm 0.43$ & $8.2 \pm 0.58$ & $9.1 \pm 0.28$ \\
\hline $\begin{array}{c}\text { Proteus } \\
\text { mirabilis }\end{array}$ & $10.6 \pm 0.20$ & $10.2 \pm 0.26$ & $10.1 \pm 0.41$ & $9.1 \pm 0.15$ & $9.3 \pm 0.43$ & $8.3 \pm 0.30$ & $9.0 \pm 0.50$ \\
\hline
\end{tabular}

$\pm=$ Standard deviation

${ }^{\prime} \mathrm{a}^{\prime}=$ including disc diameter of $6 \mathrm{~mm}$

\section{RESULTS AND DISCUSSION}

A total of twelve honey samples from different origins were evaluated for their antibacterial activity against the Gram positive species such as Staphylococcus aureus, Streptococcus pyogenes, and the Gram negative species such as Escherichia coli, Pseudomonas aeruginosa, and Proteus mirabilis. Among the twelve honey samples studied S1 and W1 honey samples shows maximum antibacterial activity especially against Staphylococcus aureus. The average diameter of the inhibition zones produced by these samples was $12.9 \mathrm{~mm}$. The growth of bacteria was also inhibited by these honey samples; although to a lesser extent. Among the honey samples normally the winter honey shows the maximum inhibition zone (average $11.55 \mathrm{~mm}$ ). 
Among the summer honey samples S1 honey samples shows maximum inhibition zone (average $10.0 \mathrm{~mm}$ ), whereas the honey sample S6 shows minimum inhibition zone (average $7.42 \mathrm{~mm}$ ) Among the winter honey samples the honey sample W1 shows the Maximum inhibition zone (average $11.58 \mathrm{~mm}$ ), Whereas the honey sample S6 shows the Minimum inhibition zone (average $8.2 \mathrm{~mm}$ ).

Among the bacterial strains tested Staphylococcus aureus the most sensitive against all honey samples (average inhibition zone is $10.42 \mathrm{~mm}$ ), whereas the Pseudomonas aeruginosa shows the less sensitive against all honey samples.

Antibiotic resistance of bacteria is on increase the discovery of alternative therapeutic agents is urgently needed. Honey possesses therapeutic potential, including would healing properties and antimicrobial activity.

The antimicrobial properties of honey can be attributed to several factors like high osmotic pressure, low pH (Molan,1992a and 1992b).Among the twelve honey samples the honey samples collected in winter (W1, W2, W3, W4, W5 \& W6) Shows the maximum inhibition zone.

\section{CONCLUSION}

The present study reveals that among the twelve honey samples tested against the pathogenic bacteria the six winter honey samples were more effective in inhibiting the pathogenic bacteria than the summer honey samples. All the honey samples were more effective against staphylococcus aureus than the other bacteria.

\section{References}

[1] Molan, P. C 1992a. The antibacterial activity of honey: 1. The nature of antibacterial activity of honey. Bee world. 73: 5-28.

[2] Bauer, A. W, Kirby WMM. Sherirs JC, Turck M 1996. Antibiotic susceptibility testing by standard single disk method. Am. J. Clin. Pathol. 45: 433-496.

[3] Molan, PC. 1992b. The antibacterial activity of honey: 2. Variation in potency of antibacterial activity of honey. Bee World. 73: 59-76.

[4] Adebolu, T. 2005.Effect of natural honey on local isolates of diarrhea-causing bacteria in southwestern Nigeria. In African Journal of Biotechnology, vol. 4, 2005, no. 10, p.1172-1174.

[5] Ahmed, M. Djebli, N. Hammoudi, S. Aissat, S. Akila, B. Hemida, H.2012. Additive potential of ginger starch on antifungal potency of ginger starch on antifungalpotency of honey against Candida albicans. In Asian Pacific Journal of TropicalBiomedicine, vol. 2, 2012, no. 4, p. 253-255.

[6] Al-Waili, N. Akmal, M. Al-Waili, F. Salomn, K. Ali, A. 2005. The antimicrobial potential of honey from United Arab Emirates on some microbial isolates. In Medical Science monitor,vol. 11, 2005, no. 12, p.433-438.

[7] Armstrong, S. and G. W. Otis, 1995. The antibacterial properties of honey. Bee Culture, 123(9): 500-502. 
[8] Asadi-Pooya, A. Pnjehshahin, M. Beheshti, S. 2003. The antimycobacterial effect of honey: an in vitro study. In Rivista di biologia, vol. 66, 2003, no. 3, p. 491-496.

[9] Basson, N. J., duToit, I. J. and Grobler, S. R. (1994). Antibacterial action of honey on oral streptococci. J DentAssoc SAfr, 49:339-341.

[10] Betts, J. A. and P.C. Molan, 2002. Results of a pilottrial of manuka h oney as a dressing forinfectedchronic wounds. - A paper presented at the $4^{\text {th Australian }}$ Wound Management Association Conference, Adelaide, Australia.

[11] Brudzynski, K., 2006. Effect of hydrogen peroxide on antibacterial activities of Canadian honeys. Can. J. Microbiol., 52: 1228-1237.

[12] Cooper, R. Molan, P. Harding, K. 1999. Antibacterial activity of honey against strains of Staphylococcus aureus from infected wounds. In Journal of the Royal Society of Medicine, vol. 92, 1999, no. 9, p.283-285.

[13] Cooper, R., Molan, P. Harding, K. 2002. The sensitivity to honey of gram positive cocci of clinical significance isolated from wounds. In Journal of Applied microbiology, vol.93, 2002, no. 5, p. 857-863.

[14] Kačániová, M. Vukovic, N. Bobková, A. Fikselová, M. Rovná, K. Haščík, P. Čuboň, J. Hleba, L. Bobko, M. 2011. Antimicrobial and antiradical activity of Slovakian Honeydew honey samples. In The Journal of Microbiology, Biotechnology and Food Sciences, vol. 1, 2011, no. 3, p. 354-36.

[15] Irish, J. Carted, D. Shokohi, T. Blair, S. 2006. Honey has an antifungal effect against Candida species. In Medical Mycology, vol. 44, no. 3, p. 289-291.

[16] Koc, A. Silici, S. Ercal, B. Kasap, F. hörmet-öz, H. Mavus- Buldu, H. 2008. Antifungal Activity of Turkish Honey against Candida spp. and Trichosporon spp:an in vitro evaluation. In Medical Mycology, vol. 47, 2008, no. 7, p.707-712.

[17] Kwakman, P. Zaat, S. 2012. Antibacterial components of honey. In IUBMB Life, vol. 64, no. 1, p. 48-55.

[18] Lin, S. Molan, P. Cursons, R. 2011. The controlled in vitro susceptibility of gastrointestinal pathogens to the antibacterial effect of manuka honey. In European journal of clinical microbiology \& infectious diseases, vol. 30, 2011, no. 4, p. 569-574.

[19] Lusby P.E. and Coombes,A.L. 2005. Wilkinson JM: Bactericidal activity of different honeys against pathogenic bacteria.Arch Med Res., Int J Food Microbiol. 36:464-467.

[20] Maddocks, S. Lopez, M. Rowlands, R. Cooper, R. 2012. Manuka honeyinhibits the development of Streptococcus pyogenes biofilms and causes reduced expressionof two fibronectin binding proteins. In Microbiology, vol. 158, 2011, no. 3, p. 781-790.

[21] Molan, P., 2002. Not all honeys are the same for wound healing. Bull. Eur. Tissue Rep. Soc., 9: 5-6.

[22] Mullai, V. and T. Menon, 2007. T Bactericidal Activity of Different Types of Honey gainst Clinical and Environmental Isolates of Pseudomonas aeruginosa. J. Altern.Complement. Med., 13: 439-442.

[23] Mundo, M. A., Padilla-Zakour, O. I. and Worobo, R. W. 2004. Growth inhibition of foodborne pathogens and food spoilage organisms by select raw honeys. , 97:1-8. 
[24] Snow, M. and M. Manley-Harris, 2004. On the nature of non-peroxide antibacterial activity in New Zealand Manuka honey. Food Chem., 84: 145-147.

[25] Voidarou, C. Alexopoulos, A. Plessas, S. Karapanou, A. Mantzourani, I. Stavropoulou, E. Fotou, K. Tzora, A. Skoufos, I. Bezirtzoglou, E. 2011. Antibacterial activity of different honeys against pathogenic Bacteria. In Anaerobe, vol. 17, 2011, no. 6, p. 375-379.

[26] Wahdan, H. 1998. Causes of the antimicrobial activity of honey. In Infection, vol. 26, 1998, no. 1, p.26-31. 